OPEN ACCESS

Edited by:

Jianhua Fan,

East China University of Science and

Technology, China

Reviewed by:

Jianhui Zhang

North Carolina Central University,

United States

Arshad Ali,

South China Normal University, China Arumugam Muthu,

Council of Scientific and Industrial Research (CSIR), India

*Correspondence:

Quanxi Wang

wangqx@shnu.edu.cn

Specialty section:

This article was submitted to

Plant Biotechnology,

a section of the journal

Frontiers in Plant Science

Received: 07 December 2017

Accepted: 15 May 2018

Published: 28 June 2018

Citation:

Xu L, Cheng X and Wang Q (2018) Enhanced Lipid Production in Chlamydomonas reinhardtii by Co-culturing With Azotobacter chroococcum. Front. Plant Sci. 9:741. doi: 10.3389/fpls.2018.00741

\section{Enhanced Lipid Production in Chlamydomonas reinhardtii by Co-culturing With Azotobacter chroococcum}

\author{
Lili Xu, Xianglong Cheng and Quanxi Wang* \\ Department of Biology, College of Life and Environmental Science, Shanghai Normal University, Shanghai, China
}

The green algae, Chlamydomonas reinhardtii, is one of the model species used to study lipid production, although research has focused on nitrogen-deficient cultures, that inhibit the development of biomass by $C$. reinhardtii and limit lipid production. In this study, Azotobacter chroococcum was added to the algal culture to improve lipid accumulation and productivity of $C$. reinhardtii. The maximum lipid content and production of $C$. reinhardtii in the co-culture were $65.85 \%$ and $387.76 \mathrm{mg} / \mathrm{L}$, respectively, which were 2.3 and 5.9 times the control's levels of $29.11 \%$ and $65.99 \mathrm{mg} / \mathrm{L}$, respectively. The maximum lipid productivity of $C$. reinhardtii in the co-culture was $141.86 \mathrm{mg} /(\mathrm{L} \cdot$ day), which was 19.4 times the control's levels of $7.33 \mathrm{mg} /(\mathrm{L} \cdot$ day $)$. These increases were attributed to the enhanced growth and biomass and the change in the activity of enzymes related to lipid regulation (ACCase, DGAT, and PDAT). Compared to the conventional strategy of nitrogen deprivation, $A$. chroococcum added to the culture of $C$. reinhardtii resulted in higher lipid accumulation and activity, greater efficiency in the conversion of proteins to lipids, higher biomass, and increased growth of $C$. reinhardtii. Therefore, using A. chroococcum to improve the growth and biomass of $C$. reinhardtii is an efficient, rapid, and economically viable strategy for enhancing lipid production in C. reinhardtii.

Keywords: Chlamydomonas reinhardtii, Azotobacter chroococcum, co-culture, lipid production, biomass

\section{INTRODUCTION}

The global supply of traditional fossil fuels is limited and the combustion of fossil fuels produces $\mathrm{CO}_{2}$ and other greenhouse gases that cause climate change (Hui et al., 2016). There is an urgent need for new types of renewable, clean energy resources. Biodiesel is a renewable and biodegradable fuel that is considered environmentally friendly because it is produced from unprocessed or recycled vegetable oils and animal fats through various chemical reactions (Ho et al., 2014). Thesupply and price of raw materials are the key limiting factors of biodiesel applications; thus, cheap and renewable raw materials for biodiesel production are required for the large-scale utilization of biodiesel.

Through photosynthesis, algae can convert $\mathrm{CO}_{2}$ and water to $\mathrm{O}_{2}$ and macromolecular organic matter in the form of carbohydrates and lipids (Hu et al., 2008; Scott et al., 2010). Under certain stress conditions, such as high light intensity or nutrient deficiency, some algae can accumulate large amounts of lipids, such as triacylglycerides. Because of their fast growth, high lipid content, 
and optimized lipid composition, microalgae are ideal materials for biodiesel production ( $\mathrm{Hu}$ et al., 2008; Wang et al., 2009; Siaut et al., 2011). Chlamydomonas reinhardtii (C. reinhardtii) is a unicellular green algae species, whose genome has been fully sequenced. It grows quickly, costs little to cultivate, and can produce lipids under nitrogen-deficient conditions; thus, it has been widely used for lipid production (Park et al., 2015). As with other microalgae, the growth of $C$. reinhardtii is repressed by nitrogen deficiency. Algal biomass and lipid accumulation showed a negative correlation with nitrogen deficiency (Park et al., 2013, 2015; Fan et al., 2014). This has resulted in lower lipid accumulation and productivity than its theoretical capacity. The ideal model involves increasing lipid accumulation using green algae by removing nitrogen from the medium without limiting the algal biomass. In order to improve the lipid accumulation by C. reinhardtii, we need to identify an effective way to increase the biomass of $C$. reinhardtii in the absence of nitrogen.

In natural environments, bacteria and algae share a complex ecological relationship. Some bacteria can promote the growth and biomass of algae by metabolic complementarity. Ietswaart et al. (1994) found that two obligate aerobic bacteria, Pseudomonas diminuta and $P$. vesicularis, could promote the growth of Scnedesmus obliquus and Chlorella sp. Bell et al. (1974) reported that Skeletonema costatum cultivated alongside Pseudomonas strain grew faster than in its absence and did not survive without Pseudomonas. Riquelm et al. (1988) suggested that the glycoprotein secreted by Pseudomonas promoted the growth of $A$. glacialis. Some marine microalgae and heterotrophic bacteria, when co-grown, can secrete extracellular enzymes or specific growth factors that promote each other's growth. These include Bacillus halmapalus and Alexandrium tamarense (Zheng et al., 2002). Azotobacter chroococcum (A. chroococcum) is a nitrogen-fixing aerobic bacteria species that can draw nitrogen from the air (Walker and Yater, 1978). It is widely used in the study of biochemical processes, electron transport, and iron storage (Krakow and Ochoa, 1963). Great progress has been made in understanding the biochemistry and genetics of hydrogen metabolism and nitrogen fixation by studying $A$. chroococcum. These studies determined the ability of $A$. chroococcum to stimulate plant growth through the production of plant growth substances and fixed nitrogen, and other factors (Rubenchik, 1963).

In this work, to increase the biomass and lipid accumulation of $C$. reinhardtii, we co-cultured $C$. reinhardtii cc849 with A. chroococcum under nitrogen-deficient conditions and investigated the underlying mechanism of the resulting increased lipid content. The lipid content and lipid productivity of C. reinhardtii, when mixed with $A$. chroococcum were monitored. The growth, biomass, cellular biochemical components and fatty acid of $C$. reinhardtii in the co-culture and pure algal culture were compared in this study. Finally, the transcription levels of the genes related to the lipid production of algae and its co-culture with $A$. chroococcum were analyzed. The special ecological relationship between green algae and bacteria was used to improve the biomass and lipid content of C. reinhardtii, which is a clean and sustainable way to produce biofuel. This research provides a novel and useful strategy to enhance the lipid accumulation and productivity of $C$. reinhardtii for treatment by the co-culture with bacteria.

\section{MATERIALS AND METHODS}

\section{Algal and Bacterial Strains and Culture Conditions}

Chlamydomonas reinhardtii cc849 was purchased from the Chlamy Center. It is a type of cell deficient strain. The algae grew in the Tris-acetate-phosphate (TAP) medium $(\mathrm{pH}=7.0)$ under light conditions of $100 \mu \mathrm{E} \cdot \mathrm{m}^{-2} \cdot \mathrm{s}^{-1}$ at $25 \pm 1^{\circ} \mathrm{C}$ (Harris, 2009). The cell density was determined by absorbance at $750 \mathrm{~nm}$ $\left(\mathrm{OD}_{750}\right)$. Chlorophyll of $C$. reinhardtii was extracted with alcohol. Cells $(1 \mathrm{~mL})$ were extracted and centrifuged at 12,000 $\mathrm{g}$ for $1 \mathrm{~min}$ at room temperature and the supernatant was removed. Then, $1 \mathrm{~mL}$ of $95 \%$ alcohol was added to the tube and the pellet was resuspended and centrifuged at $12,000 \mathrm{~g}$ for $1 \mathrm{~min}$ at room temperature (Harris, 2009). The supernatant was extracted and absorbance was measured at $665 \mathrm{~nm}$ and $649 \mathrm{~nm}$ (Wu et al., 2011).

Chlorophyll content $(\mathrm{mg} / \mathrm{L})=\mathrm{OD}_{665} \times 6.01+\mathrm{OD}_{649} \times 20.04$

Azotobacter chroococcum No 1.0233 was purchased from China General Microbiological Culture Collection Center (CGMCC) and cultured in a nitrogen fixation medium $(\mathrm{pH}=7.0)$ at $28 \pm$ $1^{\circ} \mathrm{C}$. The cell density is expressed as the absorbance at $600 \mathrm{~nm}$ (OD ${ }_{600}$ ) (Winogradski, 1935). The cell density of A. chroococcum in the co-culture was obtained by $\mathrm{OD}_{600}$ of the mixture minus the $\mathrm{OD}_{600}$ of pure algal culture.

$$
\begin{aligned}
\mathrm{OD}_{600} \text { (bacteria in co-culture) }= & \mathrm{OD}_{600} \text { (co-culture) } \\
& -\mathrm{OD}_{600} \text { (pure algal culture). }
\end{aligned}
$$

\section{Co-culture of Algae and Bacteria for Lipid Production}

The algal cells in the culture flask were harvested by centrifugation at $4,500 \mathrm{~g}$ and $25^{\circ} \mathrm{C}$ for $5 \mathrm{~min}$ when they grew to saturation. The algal pellet was washed gently with the TAP-N medium three times to remove nitrogen thoroughly (Wan et al., 2013). The bacterial medium was also harvested by centrifugation at 5,000 $\mathrm{g}$ and $25^{\circ} \mathrm{C}$ for $5 \mathrm{~min}$ when it is grown to saturation then resuspended with the TAP-N medium three times. The bacterial pellet was resuspended with a suitable volume of the TAP-N medium so that $\mathrm{OD}_{600}=1.0$. Then, $10 \mathrm{~mL}$ of the resuspended bacterial sample was added to a $500 \mathrm{~mL}$ flask followed by the addition of $0.5 \mathrm{mg}$ algae. Finally, the TAP-N medium was replenished in the flask. The sample in the flask was shaken gently so that bacteria and algae are mixed well. The flask was placed under $200 \mu \mathrm{E} \cdot \mathrm{m}^{-2} \cdot \mathrm{s}^{-1}$.

Samples were dried in an oven at $80^{\circ} \mathrm{C}$ for $24 \mathrm{~h}$ until the weight ceased to decrease (dry weight is designated as DW here). Ten microliter of the bacterial culture broth was mixed with $990 \mu \mathrm{l}$ water and spreaded on a solid plate medium, then the number of colonies were counted after culturing in $28^{\circ} \mathrm{C}$ for $48 \mathrm{~h}$. The cells number $/ \mathrm{mL}$ of algae was obtain through the 
microscope observation. The linear relationship between cells number $/ \mathrm{mL}$ and biomass of $C$. reinhardtii and $A$. chroococcum were determined. The cells number/mL of algae and bacteria in the co-culture could obtain by microscopy and plate medium coating, respectively. The biomass of bacteria and algae in the co-culture medium were obtained by the following equation:

$$
\begin{aligned}
\mathrm{DW}_{\text {bacteria }} & =\text { Cell number } / \mathrm{mL} \times 0.0557+0.032 R^{2}=0.9931 \\
\mathrm{DW}_{\text {algae }} & =\text { Cell number } / \mathrm{mL} \times 0.8451+0.263 R^{2}=0.9923
\end{aligned}
$$

\section{Observation of C. reinhardtii and \\ A. chroococcum by Microscopy}

In this experiment, $1 \mathrm{~mL}$ of the cells of the culture was stained with Nile Red (Sigma) by adding the dye to a final concentration of $1 \mathrm{mg} / \mathrm{mL}$ and running the reaction for $15 \mathrm{~min}$. The brightfield images of $C$. reinhardtii cells grown in the TAP-N media were captured using a confocal laser scanning microscope (Nikon Eclipse 80i) equipped with a digital camera (Nikon DSRi1), respectively. Subsequently, the corresponding fluorescence images of the Nile Red signal were captured by the excitation line at $488 \mathrm{~nm}$ (Chen et al., 2009; Boyle et al., 2012).

\section{Extraction and Detection of Lipid Content}

Total lipids were extracted using a modified version of the protocol reported by Bligh and Dyer (1959). Here, $400 \mathrm{~mL}$ of algal cells were harvested by centrifuging at 7,500 $\mathrm{g}$ for $10 \mathrm{~min}$ and the sediment was washed with fresh TAP-N medium three times. Solid samples were placed in dry weighing bottles and dried in an oven at $80^{\circ} \mathrm{C}$ for $24 \mathrm{~h}$ until the weight ceased to decrease. Then, $0.2 \mathrm{~g}$ (weight is designated $\mathrm{W}_{0}$ ) of dry cells were transferred into the centrifugal tube. Subsequently, $5 \mathrm{~mL}$ mixture of chloroform and methyl alcohol at a volume ratio of 1:1 were added to the centrifugal tube. The cells in the centrifugal tube were shaken for $30 \mathrm{~min}$, placed in a centrifuge tube, and centrifuged at $8,000 \mathrm{~g}$ for $10 \mathrm{~min}$. All the steps were repeated until the supernatant was colorless. The supernatant was collected (weight is designated $\mathrm{W}_{1}$ ) and transferred, to a dry rotary evaporator, of known weight, and evaporated to dryness (weight was designated $\mathrm{W}_{2}$ ).

Biomass $(\mathrm{mg})=\mathrm{DW}$;

Unit biomass $(\mathrm{mg} / \mathrm{L})=\mathrm{DW} / 0.5$;

Lipid content $=\left(\mathrm{W}_{2}-\mathrm{W}_{1}\right) / \mathrm{W}_{0} \times 100 \%$;

Lipid production $(\mathrm{mg} / \mathrm{L})=\mathrm{W}_{2}$;

Lipid productivity $(\mathrm{mg} /(\mathrm{L} \cdot$ day $))=\mathrm{W}_{2} /$ day

\section{Fatty Acid Analysis of Lipid of Algae and A. chroococcum}

Fatty acids in algae were analyzed using a previously described method (Wang et al., 2013) with some modifications. First, $0.1 \mathrm{~g}$ dry sample was added to a $15 \mathrm{~mL}$ glass vial and then it was dissolved in a $2 \mathrm{~mL}$ methanolic $\mathrm{HCl}$ and $3 \mathrm{~mL}$ chloroformmethanol solution (volume ratio 1:1). Finally, $1 \mathrm{~mL}$ heptane containing $50 \mu \mathrm{g}$ heptadecanoic acid methyl ester $\left(\mathrm{C}_{18} \mathrm{H}_{37}-\right.$ $\left.\mathrm{COOCH}_{3}\right)$ as the internal standard was added to the glass vial. The reaction proceeded at $85^{\circ} \mathrm{C}$ for $1 \mathrm{~h}$, after which $1 \mathrm{~mL}$ hexane was added to the vial. The solution was left to stand for $1 \mathrm{~h}$ to obtain the supernatant, which was used for FAME analysis. Samples were detected by GC-MS (Thermo, Fisher, ISQ) equipped with a flame ionization detector (FID) and Agilent HP5 GC Capillary Column $(30 \mathrm{~m} \times 0.25 \mathrm{~mm} \times 0.25 \mu \mathrm{m})$. Nitrogen was used as a carrier gas. The injector temperature was set at $290^{\circ} \mathrm{C}$ with an injection volume of $2 \mu \mathrm{L}$ under split mode $(10: 1)$. The detector temperature was set at $280^{\circ} \mathrm{C}$. The individual FAMEs were identified by comparing their retention time with those of the authentic standards.

\section{Determination of Protein Content and Carbohydrate Content}

The protein content of $C$. reinhardtii was measured using the BCA method (Hu et al., 2008). Algal cells ( $5 \mathrm{~mL}$ ) were harvested and centrifuged at $7,500 \mathrm{~g}$ for $10 \mathrm{~min}$. The supernatant was discarded. Subsequently, $1 \mathrm{~mL}$ of $15 \mathrm{mM} \mathrm{KH}_{2} \mathrm{PO}_{4}$ (pH 4.5) and $2 \mathrm{~mL}$ of $20 \% \mathrm{NaOH}$ were added to the tube and shaken for $30 \mathrm{~s}$. The tube was put into boiling water for $10 \mathrm{~min}$, and then centrifuged at 7,500 g for $10 \mathrm{~min}$. The supernatant was collected and used to assay the protein content using Pierce BCA protein assay kit (Thermo). Bovine serum albumin was used as the standard sample to obtain a standard curve. Subsequently, the protein content was calculated from the absorbance measured using the microplate reader at $560 \mathrm{~nm}$ and the standard curve. Carbohydrate content of $C$. reinhardtii was detected by anthrone colorimetry (Dubois et al., 1956). First, $10 \mathrm{mg}$ of algal powder was put into a tube and synchronously, $0.5 \mathrm{~N} \mathrm{H}_{2} \mathrm{SO}_{4}$ was added. Then the tube was incubated in a bath at $80^{\circ} \mathrm{C}$ for $1 \mathrm{~h}$. Finally, the reactant was centrifuged at $8,000 \mathrm{~g}$ for $5 \mathrm{~min}$ to collect the supernatant and the steps were repeated once. The supernatant was extracted and the absorbance was measured at $625 \mathrm{~nm}$ (Dubois et al., 1956).

\section{RNA Extraction and Real-Time Quantitative PCR}

Two milliliters of cells were collected from the samples on days 0 , 1,5 , and 9 in the TAP-N medium and RNA was extracted using a QIAGEN Plant Mini Kit. The concentration and purity of the extracted RNA were measured using a UV spectrophotometer. Single stranded cDNA was synthesized from $2 \mu \mathrm{g}$ of DNAdigested total RNA following the reverse transcription protocol provided by the manufacturer (Promega ${ }^{\mathrm{TM}}$ ). Transcriptional levels of genes related to lipid accumulation were detected using real-time quantitative PCR. Primers for quantitative real-time RT-PCR were designed using the Primer 5 software and are shown in Table 1. Real-time quantitative PCR was performed as stipulated by the manufacturer of the SYBR Green real-time PCR Master Mix Kit (TOYOBO ${ }^{\mathrm{TM}}$, Japan). The actin gene from C. reinhardtii was used as an internal control to normalize the differences between the loading amounts of the template (Makarova et al., 2007). Each PCR reaction contained $1 \mu \mathrm{L}$ (8 ng) of cDNA, $10 \mu \mathrm{L}$ of SYBR Green $2 \times$ Master Mix, and $1 \mu \mathrm{L}$ of each gene-specific primer pair $(10 \mathrm{mM})$ to a final volume of 20 $\mu \mathrm{L}$. PCR was performed as follows: $95^{\circ} \mathrm{C}$ for $10 \mathrm{~min}$ followed by 40 cycles at $95^{\circ} \mathrm{C}$ for $10 \mathrm{~s}, 60^{\circ} \mathrm{C}$ for $1 \mathrm{~min}$, and $72^{\circ} \mathrm{C}$ for 30 s. PCR products were analyzed using the Dissociation Curves 
Software of ABI. The $2^{-\Delta \Delta c t}$ method was used to calculate the fold changes of differentially expressed genes.

\section{Statistical Analysis}

All experiments were repeated three times independently, and data were recorded as the mean with SD. Statistical analyses were conducted using SPSS 19.0. Spearman correlation coefficients were computed. The results with a $P$-value $<0.05$ was considered statistically significant. "*” indicates a significant differences between the experimental and control groups.

\section{RESULTS AND DISCUSSION}

After A. chroococcum was added to the algal culture, the maximum lipid production of $C$. reinhardtii in the co-culture

TABLE 1 | Primers used for real-time quantitative PCR.

\begin{tabular}{|c|c|c|}
\hline Gene Name & Accesion Number & Primer \\
\hline ACTIN & XM_001699016 & 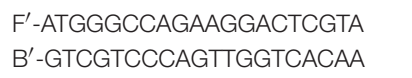 \\
\hline$A C C$ & XM_001703135 & 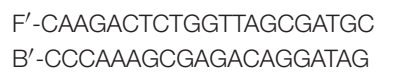 \\
\hline DGAT1 & XM_001693137 & $\begin{array}{l}\text { F'-ACTGGTGGAATGCGGCTAC } \\
\text { B'-TAGCAGCTCGTGGAACACAG }\end{array}$ \\
\hline DGTT1 & KC788199.1 & $\begin{array}{l}\text { F'-CGGCGGAGGGAACTTAT }^{\prime} \text { B'-GAAGAGGTGCGGGGACA }^{\prime}\end{array}$ \\
\hline DGTT2 & KC788200.1 & 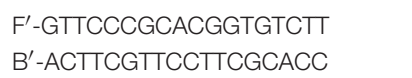 \\
\hline DGTT3 & KC788201.1 & $\begin{array}{l}\text { F'-GTCAGAGCCAAGTGCTGGAC } \\
\text { B'- TCCACCTCCTTGTCGAACTC }\end{array}$ \\
\hline DGTT4 & KC788202.1 & $\begin{array}{l}\text { F'-TGCCAGATGGAAGGTGGAGTG } \\
\text { B'-GTAAGCATGTGCGGTGAAGGG }\end{array}$ \\
\hline DGTT5 & XM_001701615.1 & 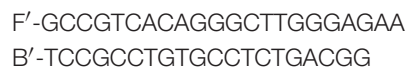 \\
\hline PDAT1 & AFB 73928 & 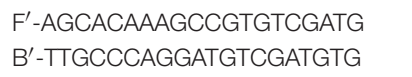 \\
\hline PEPC2 & XM_001695765 & 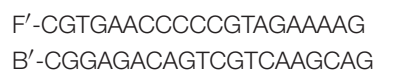 \\
\hline
\end{tabular}

was $387.76 \mathrm{mg} / \mathrm{L}$, which was $65.85 \%$ of the composition of the algal cell. The maximum lipid productivity of C. reinhardtii in the co-culture was $141.86 \mathrm{mg} /(\mathrm{L} \cdot$ day), which was 19.4 times the control's value of $7.33 \mathrm{mg} /(\mathrm{L} \cdot$ day $)$. These were attributed to enhanced growth and biomass. Furthermore, compared with the controls, the activity of enzymes related to lipid regulation, ACCase, DGAT, and PDAT was changed.

\section{Growth and Biomass of Algae Co-cultured With A. chroococcum}

Lipid production was directly related to algal biomass; thus, the growth and biomass of algae and the algae co-cultured with $A$. chroococcum were detected under nitrogen deprived conditions. The initial $\mathrm{OD}_{750}$ value of both pure algae and the algae co-cultured with $A$. chroococcum was 1.42 . After nitrogen deprivation, $\mathrm{OD}_{750}$ of pure algae gradually decreased and reached a minimum value of 0.91 , while $\mathrm{OD}_{750}$ of algae co-cultured with A. chroococcum increased sharply, especially after day 3 . It peaked at 3.75, which was 4.1 times the control value, on day 9 (Figure 1A). Consistent with the change in $\mathrm{OD}_{750}$, the initial chlorophyll content of both pure algae and algae co-cultured with A. chroococcum was $9.95 \mathrm{mg} / \mathrm{mL}$. After nitrogen starvation chlorophyll content of pure algae decreased slightly and reached the minimum value of $4.85 \mathrm{mg} / \mathrm{mL}$ on day 9 . Conversely, the chlorophyll content of algae co-cultured with A. chroococcum increased significantly after day 3. It peaked at $39.13 \mathrm{mg} / \mathrm{mL}$, which was 8.1 times that of pure algae on day 9 (Figure 1B). A significant difference in the growth of algae co-cultured with $A$. chroococcum and pure algal culture was detected by $t$-test on days $3,5,7$, and $9(p<0.05)$.

The growth of $A$. chroococcum co-cultured with algae in TAP$\mathrm{N}$ was monitored and the results are shown in Figure 2. Pure algae cells in TAP and TAP-N media were used as controls. The results indicated that the initial $\mathrm{OD}_{600}$ value of both pure A. chroococcum and A. chroococcum co-cultured with algae was 0.006 . The $\mathrm{OD}_{600}$ value of pure $A$. chroococcum in both media increased slightly from day 1 to day 9 and reached the maximum value of 0.15 and 0.07 on day 9 , respectively. The $\mathrm{OD}_{600}$ value of
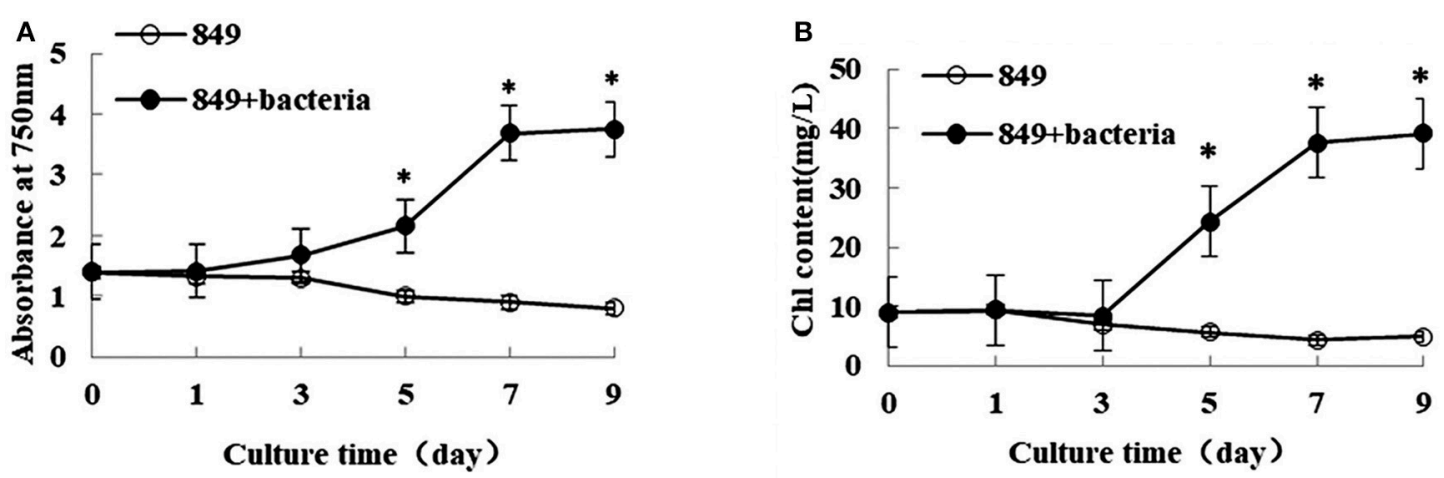

FIGURE 1 | $O D_{750}$ (A) and chlorophyll content (B) of algae in the co-culture were measured on days 0, 1, 3, 5, 7, and 9 after incubation in a nitrogen-deprived medium. Pure algae culture was used as the control. Light intensity was $200 \mu \mathrm{E} \cdot \mathrm{m}^{-2} \cdot \mathrm{s}^{-1}$ and the volume ratio of bacteria $\left(\mathrm{OD}_{600}=1.0\right)$ and $\left(\mathrm{OD}_{750}=1.0\right)$ was $1: 40$. *significant difference between the experimental and control groups. The vertical bars indicate standard errors calculated from at least three independent experiments. 


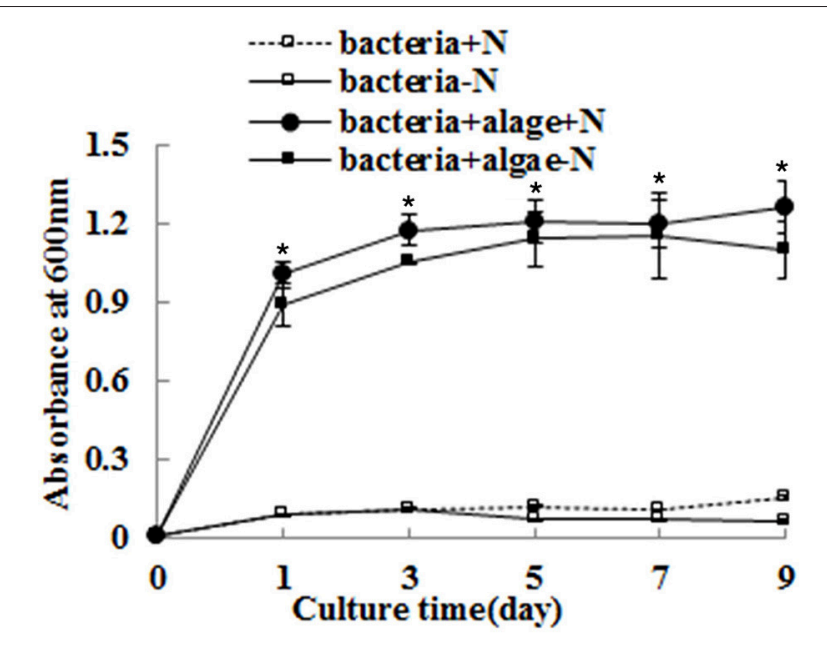

FIGURE 2 | The growth of $A$. chroococcum co-cultured with algae were measured in TAP and TAP-N media. Pure bacterial culture in both media was used as controls. Light intensity was $200 \mu \mathrm{E} \cdot \mathrm{m}^{-2} \cdot \mathrm{s}^{-1}$. The same condition as the algae in the co-culture produced lipids. The volume ratio of bacteria $\left(O D_{600}=1.0\right)$ and algae $\left(O D_{750}=1.0\right)$ was 1:40. * significant difference between the experimental and control groups. The vertical bars indicate standard errors calculated from at least three independent experiments.

A. chroococcum co-cultured with algae in both media increased significantly and reached the maximum value of 1.27 and 1.16 on day 9 and day 7, respectively. A significant difference between the growth of $A$. chroococcum co-cultured with algae and pure algae in the TAP and TAP-N media was detected by $t$-test on days 1,3 , 5,7 , and $9(p<0.05)$.

The biomass of algae co-cultured with A. chroococcum was also monitored and the results are shown in Figure 3. Pure algae and bacteria were used as controls. Biomass of pure algae and pure bacteria was labeled by the dry weight (DW) of algal and bacterial cells. Biomass of algae co-cultured with A. chroococcum was calculated by reducing the weight of the pure bacteria cells (Figure 3). The results indicated that nitrogen deprivation caused a decline in the biomass of pure algae. However, the biomass of algae co-cultured with $A$. chroococcum increased (Figure 3 ). The total biomass of the pure algae decreased from $95.00 \mathrm{mg}$ to the minimum value of $90.01 \mathrm{mg}$ on day 9 (Figure 3). Total biomass of the algae mixed with $A$. chroococcum dramatically increased and reached the maximum value of $265 \mathrm{mg}, 2.9$ times the control. As with the change in total biomass, the initial unit biomass of pure algae and samples mixed with $A$. chroococcum was $211 \mathrm{mg}$. The unit biomass of pure algae decreased slightly to the minimum value of $200.00 \mathrm{mg}$ on day 9, while the total biomass of algae mixed with $A$. chroococcum increased to the maximum value of $588 \mathrm{mg}$, also 2.9 times the control. A significant difference between the biomass of algae co-cultured with A. chroococcum and pure algal culture was observed by t-test on $3,5,7$, and 9 days $(p<0.05)$. The number of bacteria added to the algal culture was mostly small. Total biomass and unit biomass of pure $A$. chroococcum slightly increased from the initial value of $0.006 \mathrm{mg}$ and $0.015 \mathrm{mg} / \mathrm{L}$ to the maximum value of $0.010 \mathrm{mg}$ and $0.025 \mathrm{mg} / \mathrm{L}$, respectively (Figure 3).

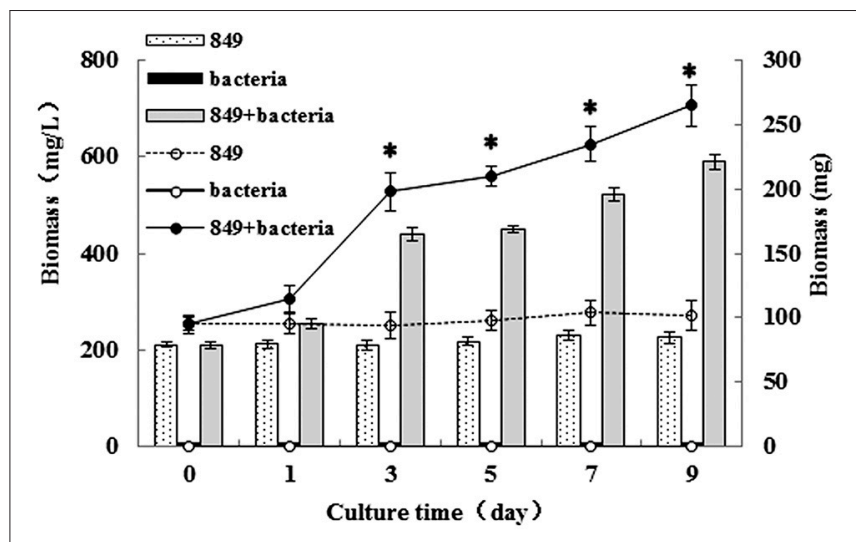

FIGURE 3 | Unit biomass ( $\mathrm{mg} / \mathrm{L})$ and total biomass $(\mathrm{mg})$ of algae in the co-culture were measured on days $0,1,3,5,7$, and 9 after incubation in a nitrogen-deprived medium. Pure algae culture was used as the controls. Unit biomass is shown with bars and total biomass is shown with dashed and solid lines, respectively. *significant difference between the experimental and control groups. The vertical bars indicate standard errors calculated from at least three independent experiments.

Nitrogen is essential to the growth of micro-algae; thus, the growth and biomass of micro-algae are commonly repressed (Fan et al., 2014). In this study, the growth and biomass of C. reinhardtii exhibited little inhibition after 3 days, while the growth and biomass of $C$. reinhardtii co-cultured with A. chroococcum increased sharply, this resulted in the nitrogen reservoir could sustain the cell growth for a few days. This suggests that the nitrogen reservoir could sustain cell growth for a few days; thus, there were no differences in the growth on the first 3 days of nitrogen deficiency (Fan et al., 2014). With the consumption of stored nitrogen, the growth and biomass of $C$. reinhardtii were repressed. Conversely, the growth and biomass of $C$. reinhardtii co-cultured with $A$. chroococcum increased significantly (Figures 1, 3). A. chroococcum is a type of nitrogen-fixing aerobic bacteria that can draw nitrogen from the air (Walker and Yater, 1978); therefore, the nitrogen in the medium is not needed. In our research, the growth of pure A. chroococcum both in TAP and TAP-N media was similar, while the growth of $A$. chroococcum increased after it was co-cultured with algae in both media (Figure 2). This result indicated that nitrogen is not a limiting factor for the growth of $A$. chroococcum. Algae and bacteria exhibit mutually beneficial complex symbiotic relationships. Bacteria release a lot of extracellular metabolites, such as amino acids, enzymes, vitamins, carbohydrates, and lipids into the surrounding environment, which promote the growth of algae. Algal and bacterial growth is also promoted through metabolic regulations and materials exchange. The growth of S. obliquus and Chlorella increased by their exposure to $P$. diminuta and P. vesicularis (Ietswaart et al., 1994); the growth of Pseudomonas cultivated alongside Skeletonema costatum was more pronounced than that of Pseudomonas cultivated alone (Bell et al., 1974); Pseudomonas could secrete glycoprotein to A. glacialis, which led to their further growth (Riquelm et al., 1988). In our previous work, Bradyrhizobium japonicum improved 
the biomass and hydrogen production of C. reinhardtii (Wu et al., 2012; Xu et al., 2016). Similarly, microalgae were always observed near the surface of one type of nitrogen-fixing bacteria by Gyurjan et al. (1984); during the process, algae and bacteria underwent exosymbiotic action by complementary metabolism. In our research, $A$. chroococcum gathered around $C$. reinhardtii and formed a specific "algae-bacteria aggregate" observable under a microscope (Figure S1). In this composite system, algae and bacteria could enhance the growth and biomass of each other through materials exchange; algae supplied carbohydrates and $\mathrm{O}_{2}$ by photosynthesis, while $A$. chroococcum could supply nitrogen and $\mathrm{CO}_{2}$ to algae by nitrogen fixation (Gyurjan et al., 1984) (Figure 4).

\section{Total Lipid Content, Lipid Production, and Lipid Productivity of Algae Co-cultured With A. chroococcum}

To analyze the effect of $A$. chroococcum on lipid production of $C$. reinhardtii in the nitrogen-deficient medium, the algal cells were pre-cultured to saturation and transferred into the nitrogen-deficient medium containing $A$. chroococcum $\left(\mathrm{OD}_{600}=1.0\right)$. The pure algal culture served as the control. Samples were extracted at specific points in time to assess the lipid content, lipid production, and lipid productivity. Nitrogen starvation enhances lipid accumulation in microalgae. Consistent with the findings of previous studies, lipid content, lipid production, and lipid productivity of pure algae increased gradually after nitrogen starvation, and those of algae cocultured with A. chroococcum increased profoundly (Figure 5).
The lipid content of $A$. chroococcum was not monitored. The maximum lipid content of algae co-cultured with A. chroococcum increased from the initial $28.00 \%$ to a maximum of $65.85 \%$ on day 9, which was 2.3 times that of the pure algae, $29.11 \%$ (Figure 5A). Correspondingly, the maximum lipid production and productivity of algae co-cultured with A. chroococcum were $387.76 \mathrm{mg} / \mathrm{L}$ and $141.86 \mathrm{mg} /(\mathrm{L} \cdot$ day $)$, which were 5.9 and 19.4 times the control values, $(65.99 \mathrm{mg} /(\mathrm{L} \cdot$ day $)$ and $7.33 \mathrm{mg} / \mathrm{L}$, respectively) on day 9 (Figure 5B). A significant difference between lipid production of algae co-cultured with A. chroococcum and pure algal culture was observed by the $t$-test on days $3,5,7$, and 9 ( $p<0.05)$. Additionally, algal cells were examined by fluorescent microscopy after staining with the lipid fluorophore Nile Red (Chen et al., 2009). As indicated by Nile Red fluorescence, lipid granules of algae in the co-culture and the lipid body were larger and more numerous than those of pure algae in the nitrogen-rich medium on days 1, 3, 5, 7 and 9 (Figure S2).

C. reinhardtii can accumulate lipid even in the absence of certain nutrients, such as nitrogen ( $\mathrm{Hu}$ et al., 2008; Yeesang and Cheirsilp, 2011; Fan et al., 2014; Park et al., 2015). Therefore, in this study, samples were transferred to a nitrogendeficient medium when cultured to saturation to induce the lipid accumulation. However, nutrient limitation stimulates lipid accumulation but does so at the expense of growth (Rodolfi et al., 2009; Li et al., 2011). Biomass productivity and lipid content are inversely correlated (Hu et al., 2008; Rodolfi et al., 2009). Similarly, in our study, the biomass of pure C. reinhardtii was lower in the nitrogen-deficient medium, but it increased significantly after it was co-cultured with A. chroococcum (Figure 3). Consistent with the increased growth and biomass

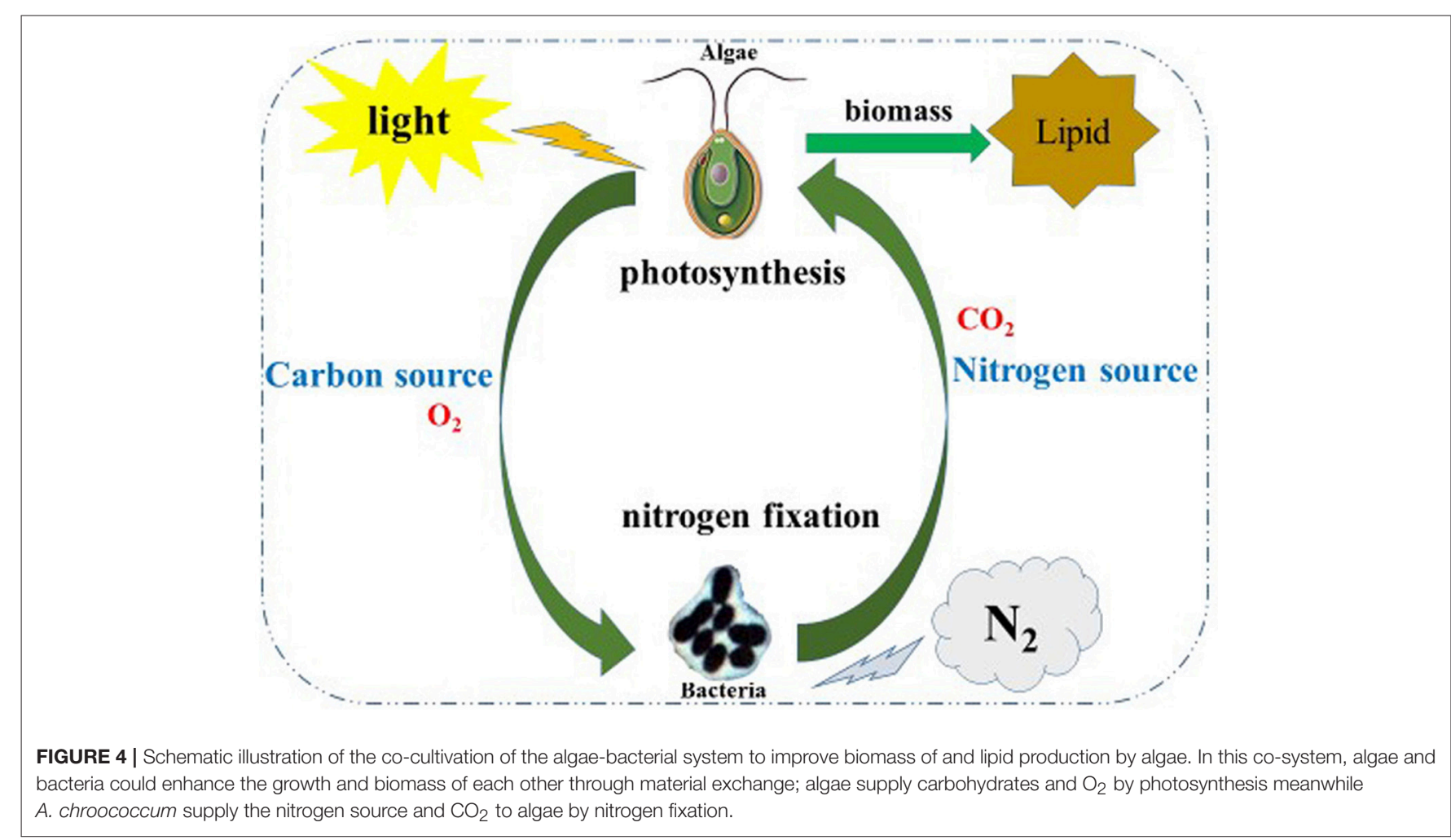



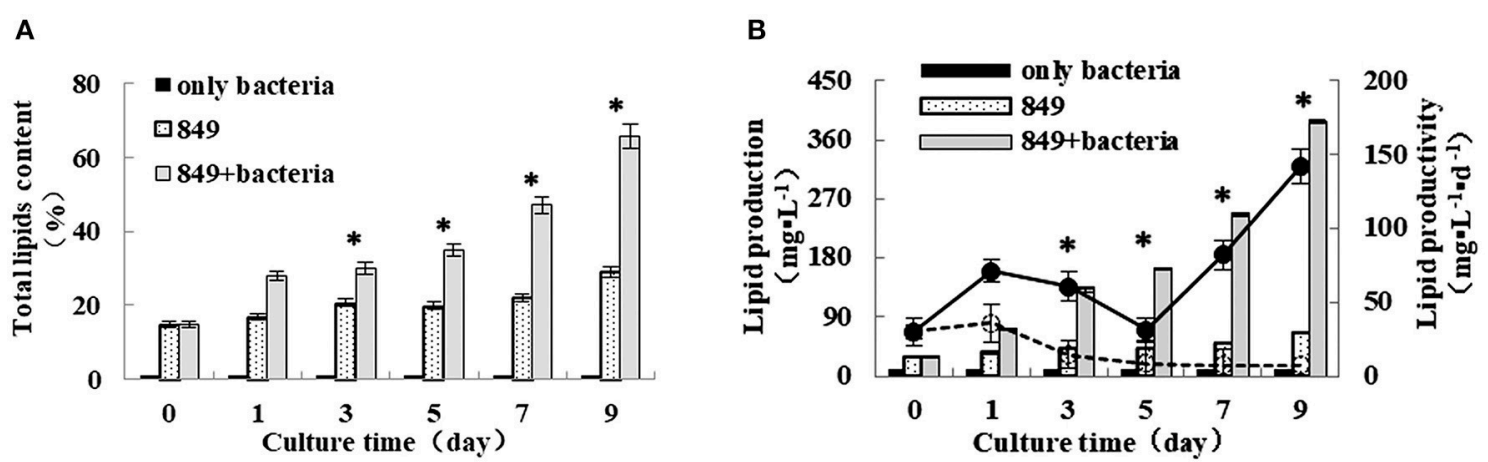

FIGURE 5 | (A) Lipid content (B) lipid production and lipid productivity of algae in the co-culture were measured on days 0, 1, 3, 5, 7, and 9 after incubation in a nitrogen-deprived medium. Pure algae culture was used as the controls. Lipid content and lipid production are shown with bars and lipid productivity of algae in the co-culture are shown with solid and dashed lines, respectively. * significant difference between the experimental and control groups. The vertical bars indicate standard errors calculated from at least three independent experiments.

of C. reinhardtii, the lipid content, lipid production, and lipid productivity of $C$. reinhardtii in the co-cultures also increased. The increased growth and biomass of $C$. reinhardtii co-cultured with $A$. chroococcum causes the increased lipid content, lipid production, and lipid productivity of $C$. reinhardtii in the coculture. Because of the number of bacteria added to the algal culture was mostly small, total biomass of pure bacteria slightly increased from the initial value of $0.006 \mathrm{mg}$ to the maximum value of $0.010 \mathrm{mg}$ (Figure 3), the lipid content of $A$. chroococcum was not monitored.

\section{Fatty Acid Analysis of Algae and A. chroococcum}

To evaluate the quality and suppliers of lipids from the mixture, the fatty acid profile of lipids in the mixture was analyzed. Pure algae and pure bacteria were used as controls. The FAME composition of algae co-cultured with bacteria and the controls (pure algae and pure bacteria) were determined by GC-MS (Table 2). The fatty acid carbon chain composition of the samples ranged from $\mathrm{C} 8$ to $\mathrm{C} 20$. The saturated fatty acid in algae, bacteria, and the mixture were $\mathrm{C} 16: 0, \mathrm{C} 18: 0$, and C19:0. The contents of $\mathrm{C} 16: 0$ in algae and the mixture were 12.79 and $12.89 \%$, respectively, while C16:0 of bacteria was only $8.15 \%$. The most abundant fatty acid in bacteria was C18:0 and its content was $47.16 \%$, which was 2.39 and 21.05 times its content in algae and bacteria. The contents of C19:0 in algae and the mixture were similar, $3.67 \%$ and $4.57 \%$, respectively. The C19:0 content in bacteria was higher than that of them, with a value of $10.97 \%$. The unsaturated fatty acid in algae, bacteria, and the mixture were polyunsaturated fatty acids, mainly C18:2, C18:3. The C18:2 content in algae, bacteria, and the mixture was very low, only the polyunsaturated fatty acids C18:2 in algae and the mixture could be monitored; their values were $2.24 \%$ and $1.28 \%$, the polyunsaturated fatty acids C18:2 were not detected in bacteria. Interestingly, C18:3 of algae was $49.53 \%$, which was almost half the ratio of total fatty acids. Inversely, there was almost no C18:3 in bacteria $(0.01 \%)$ and the amount of the C18:3 of the mixture was $17.43 \%$.
The results of the fatty acid analysis indicated that the composition and content of fatty acids in algae, bacteria, and the mixture were different. The highest contents of fatty acids in the three types of samples were C18:3, C16:1, and C18:0, respectively. In our study, the minimum and maximum values of bacterial biomass in the co-culture were $0.002 \mathrm{mg}$ and $0.010 \mathrm{mg}$ (Figure 3); therefore, the proportion of bacteria in the mixture was low and the lipid yield in the mixture was mainly supported from C. reinhardtii. Nonetheless, the contents of C19:0 in the mixture was $4.57 \%$. As we all know, algae do not produce any odd number fatty aicds in general, therefore, all the odd number fatty aicds in mixture may supported by the biomass of bacteria. The change in the fatty acid content of the mixture is not caused by the contribution of fatty acids in bacteria but by metabolic regulations and materials exchange between algae and bacteria (Gyurjan et al., 1984) (Figure 4 and Figure S1).

\section{Effect of A. chroococcum on Cellular Biochemical Components of C. reinhardtii Under Nitrogen-Deprived Conditions}

The components of algal cells were analyzed after nitrogen depletion and the results are shown in Figure 6. Total cellular composition analysis indicated that the pure algal cells consisted of $15 \%$ lipids, $11 \%$ carbohydrate, and $59 \%$ protein in the TAP medium on day 0 (Figure 6A). Nitrogen depletion caused the lipid content of pure C. reinhardtii to increase from 15 to $24 \%$ (Figure 6B), while the lipid content of C. reinhardtii in the co-culture increased significantly, peaking at $57 \%$ on day 9 (Figure 6C), which was 2.2 times that of pure C. reinhardtii. Inversely, the protein content of pure C. reinhardtii decreased from an initial value of $59 \%$ to $40 \%$ (Figure 6B), and the protein content of $C$. reinhardtii in the co-culture decreased to $13 \%$ on day 9, a change of 4.5 folds (Figure 6C). The carbohydrate content in pure $C$. reinhardtii increased from the initial value of $11-22 \%$ (Figure 6B)and the lipid content of C. reinhardtii in the co-culture increased to $25 \%$ (Figure 6C), which was 1.1 times that in pure $C$. reinhardtii. In summary, the lipid and 
TABLE 2 | Fatty acid analysis of algae co-cultured with bacteria, pure algae, and pure bacteria.

\begin{tabular}{|c|c|c|c|c|}
\hline \multirow{2}{*}{$\begin{array}{l}\text { Fatty acid } \\
\text { composition }\end{array}$} & & \multicolumn{3}{|c|}{ Content (\%) } \\
\hline & & C. reinhardtii & A. chroococcum & $\begin{array}{l}\text { C. reinhardtii + } \\
\text { A. chroococcum }\end{array}$ \\
\hline \multirow{16}{*}{$\begin{array}{l}\text { Saturated fatty } \\
\text { acids (SFA) }\end{array}$} & C8:0 & 0.01 & 0.01 & 0.07 \\
\hline & C10:0 & 0.02 & 0.14 & 0.23 \\
\hline & C11:0 & 0.00 & 0.00 & 0.01 \\
\hline & C12:0 & 0.09 & 7.88 & 1.57 \\
\hline & C13:0 & 0.01 & 0.01 & 0.01 \\
\hline & C14:0 & 2.00 & 12.43 & 4.00 \\
\hline & C15:0 & 0.42 & 0.11 & 0.23 \\
\hline & C16:0 & 12.79 & 8.15 & 12.89 \\
\hline & C17:0 & 1.22 & 0.26 & 0.97 \\
\hline & C18:0 & 19.72 & 2.24 & 47.16 \\
\hline & C19:0 & 3.67 & 10.97 & 4.57 \\
\hline & C20:0 & 0.57 & 0.01 & 2.35 \\
\hline & C21:0 & 0.01 & 0.01 & 0.02 \\
\hline & C22:0 & 0.08 & 0.00 & 0.56 \\
\hline & C23:0 & 0.00 & 0.00 & 0.01 \\
\hline & $\mathrm{C} 24: 0$ & 0.09 & 0.00 & 0.30 \\
\hline \multirow{5}{*}{$\begin{array}{l}\text { Monounsaturated } \\
\text { fatty acids (MUFA) }\end{array}$} & C14:1 & 0.02 & 0.11 & 0.06 \\
\hline & C15:1 & 0.18 & 0.00 & 0.09 \\
\hline & C16:1 & 1.40 & 38.20 & 3.94 \\
\hline & C17:1 & 0.18 & 0.49 & 0.10 \\
\hline & C20:1 & 0.19 & 0.01 & 0.14 \\
\hline \multirow{5}{*}{$\begin{array}{l}\text { Polyunsaturated } \\
\text { fatty acids (PUFA) }\end{array}$} & C18:2 & 2.24 & 0.00 & 1.28 \\
\hline & C18:3 & 49.65 & 0.01 & 17.47 \\
\hline & C20:2 & 0.02 & 0.01 & 0.02 \\
\hline & C20:3 & 0.15 & 0.00 & 0.04 \\
\hline & C20:4 & 0.01 & 0.00 & 0.02 \\
\hline
\end{tabular}

carbohydrate content of pure algae and algae in the co-culture gradually increased while the protein content decreased after the onset of nitrogen deficiency; thus, it is likely that nitrogen deficiency causes the protein in algae to transform into lipid or carbohydrates. After the addition of A. chroococcum, the lipid and carbohydrate content in algae became much higher than in pure algae, while the protein content was lower than that of in pure algae. These changes were pronounced on day 9. This indicated that $A$. chroococcum facilitated the transformation of proteins in algae to lipids or carbohydrates. Nitrogen deficiency can cause significant increase in the lipid content of microalgae and a drop in protein content. Ho et al. (2014) found that nitrogen deficiency could dramatically increase the lipid content in algae but has little effect on carbohydrate accumulation, similar to our results. Yen et al. (2013) and Siaut et al. (2011) also found that C. reinhardtii could transform protein or peptides to lipids or carbohydrates.

\section{Expression of Lipid Biosynthesis Genes in C. reinhardtii Co-cultured With A. chroococcum Under Nitrogen-Deprived Conditions}

To explore the reasons for the increased lipid production by C. reinhardtii upon addition of $A$. chroococcum, we compared the transcription levels of key genes that dominate the lipid metabolism on day 0 (in TAP medium), day 1 (starting point), day 5 (exponential growth phase), and day 9 (stationary phase) (Figure 7). The results were assessed using Spearman correlation analysis (using SPSS 19.0) to determine the quantitative relationship between the expression level of these genes and lipid content under nutrient-deficient conditions. The results provide an overall perspective for the mechanisms of improved lipid accumulation in response to nutrient stress. The actin gene from C. reinhardtii was used as an internal control and three biological repetitions were completed; the average CT value of actin was 20.3 .

Acetyl-CoA carboxylase (ACCase) is a key rate-limiting enzyme that catalyzes the first step in the synthesis of fatty acids and plays an important role in fatty-acid biosynthetic synthesis and catabolism (Cronan and Waldrop, 2002). The levels of expression of the ACC gene in C. reinhardtii in the coculture and in the control were analyzed. The results indicated that levels of expression of both $C$. reinhardtii in the coculture and pure C. reinhardtii increased with the increased lipid production and the expression of ACC in C. reinhardtii in the co-culture was higher than that of the control. A significant difference between the levels of expression of the ACC gene in algae co-cultured with A. chroococcum and in pure algal culture was observed by the t-test on days 5 and 9 ( $p<0.05)$. Adding A. chroococcum into the algal culture led to a significant increase in the nitrogen deprived medium relative to the control values and the peak level of expression of $C$. reinhardtii in the co-culture was 1.5 times control levels. The lipid content, lipid production, and lipid productivity peaked on day 9 (Figure 5). Carbon from fatty acids is made available from the pool of acetyl-Coenzyme A ( $\mathrm{CoA})$ present in the plastid and acts as a precursor for the fatty acid synthesis pathway. An ACCase can catalyze the first reaction of the fatty acid biosynthetic pathway and transform acetyl $\mathrm{CoA}$ and $\mathrm{CO}_{2}$ into malonyl CoA (Hu et al., 2008). The pattern of ACCase in fatty acid biosynthesis has been thoroughly investigated and it has been proposed that increased ACCase activity is an effective method of stimulating the accumulation of lipids in Chlorella (Hsieh and $\mathrm{Wu}, 2009$ ). Another study showed that lipid accumulation increased with the increased ACCase activity of Chlorella sorokiniana (Wan et al., 2011). Similarly, Fan et al. (Fan et al., 2014) reported that the ACCase activity of Chlorella pyrenoidosa exhibited a large increase when it was subjected to nitrogen starvation. The role of the ACCase gene expression in Crypthecodinium cohnii was studied by Liu et al. and the results indicated that the growth and lipid accumulation were higher in a C. cohnii mutant with high ACCase activity (Liu et al., 2017). In our study, the levels of expression in both $C$. reinhardtii in the co-culture and pure C. reinhardtii 

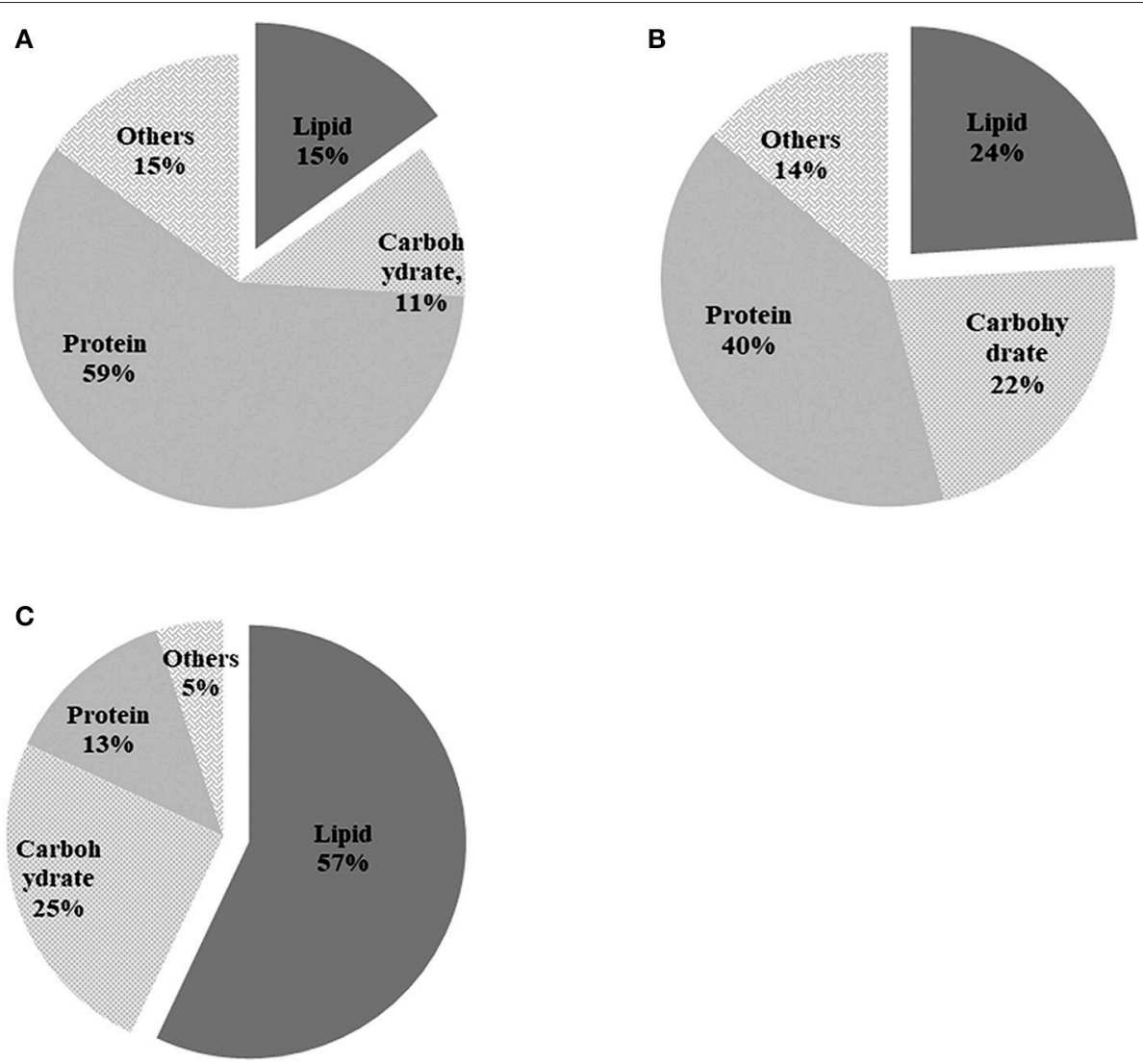

FIGURE 6 | Biochemical composition of pure algae in (A) TAP medium before incubation in the nitrogen-deprived medium; (B) pure algae; and (C) algae in the co-culture after $9 \mathrm{~d}$ of incubation in the TAP-N medium. Pure algae in the TAP medium and pure algae incubated for $9 \mathrm{~d}$ in the TAP-N medium were used as controls. Light intensity was $200 \mu \mathrm{E} \cdot \mathrm{m}^{-2} \cdot \mathrm{s}^{-1}$ and the volume ratio of bacteria $\left(O D_{600}=1.0\right)$ and $\left(O D_{750}=1.0\right)$ was $1: 40$. All the data are the means of three independent experiments with triplicates performed for each experiment.

were higher than those in pure $C$. reinhardtii cultured in a nutrient-rich medium. The levels of expression in $C$. reinhardtii co-cultured with A. chroococcum were higher than those in the controls. Our results were consistent with those of previous studies.

Diacylglycerol acyltransferase (DGAT) catalyzes the biosynthesis of triacylglycerol (TAG) by the reaction of diacylglycerol with acyl-CoA, and it is the only catalyzing enzyme in the Kennedy pathway that participates solely in the biosynthesis of TAG. The enzyme is an important regulator of lipid biosynthesis, involved in lipid metabolism and lipid deposition. There are two isoforms of DGAT, of which DGAT1 acts extensively on the metabolism of triglycerides and DGAT2 on the accumulation of TAG under nitrogen-limited conditions. In $C$. reinhardtii, the DGAT2 are encoded by five genes in C. reinhardtii, DATT1, DATT2, DATT3, DATT4, DATT5 (Sugimoto et al., 1989; Miller et al., 2010). The levels of expression of each gene of $C$. reinhardtii in the co-culture and pure algae were assessed under nitrogen deficient conditions. The results showed large differences between the sample in the co-culture and the control. The results of the real-time quantitative PCR indicated that the level of expression of DGAT1 in $C$. reinhardtii in the co-culture and pure algae decreased during day 1 , then increased through day 5. Addition of A. chroococcum led to an increase of the expression level of DGAT1 on day 9. The expression level of DGTT1 increased dramatically on day 1 , then gradually decreased from day 1 through day 9 and reached a minimum on day 9. The levels of expression levels of DGTT2 and DGTT4 in C. reinhardtii in the co-culture and pure algae decreased from day 1 to day 9 and reached a minimum on day 9 , while those of $C$. reinhardtii in the co-culture were higher than those of the control, (1.5 and 1.3 times the control levels, respectively) on day 1 . Inversely, the levels of expression of DGTT3 and DGTT5 in both co-cultured C. reinhardtii increased from day 1 to day 9 , peaking on day 9 . The levels of expression of all six DGAT genes in C. reinhardtii in the co-culture were higher than those of the controls. It is likely that adding $A$. chroococcum led to an increase in the level of expression of DGAT genes. A significant difference between the levels of expression of the DGAT1 gene in algae co-cultured with $A$. chroococcum and pure algal culture was observed by t-test on days 1 and $9(p<0.05)$; the levels of expression of the DGTT1, DGTT2, and DGTT5 genes showed significant differences on days 1,5 , and 9 ( $p<0.05$ ); the levels of expression 

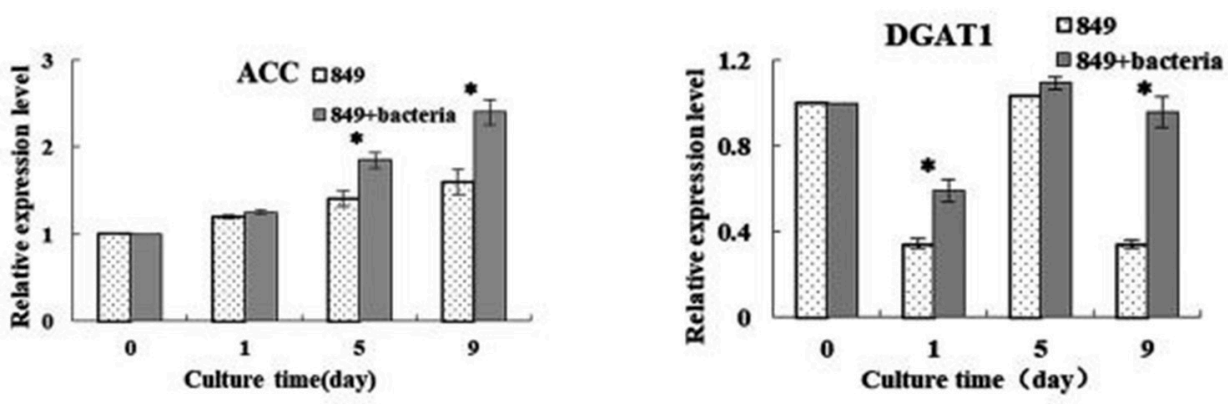

DGTT2
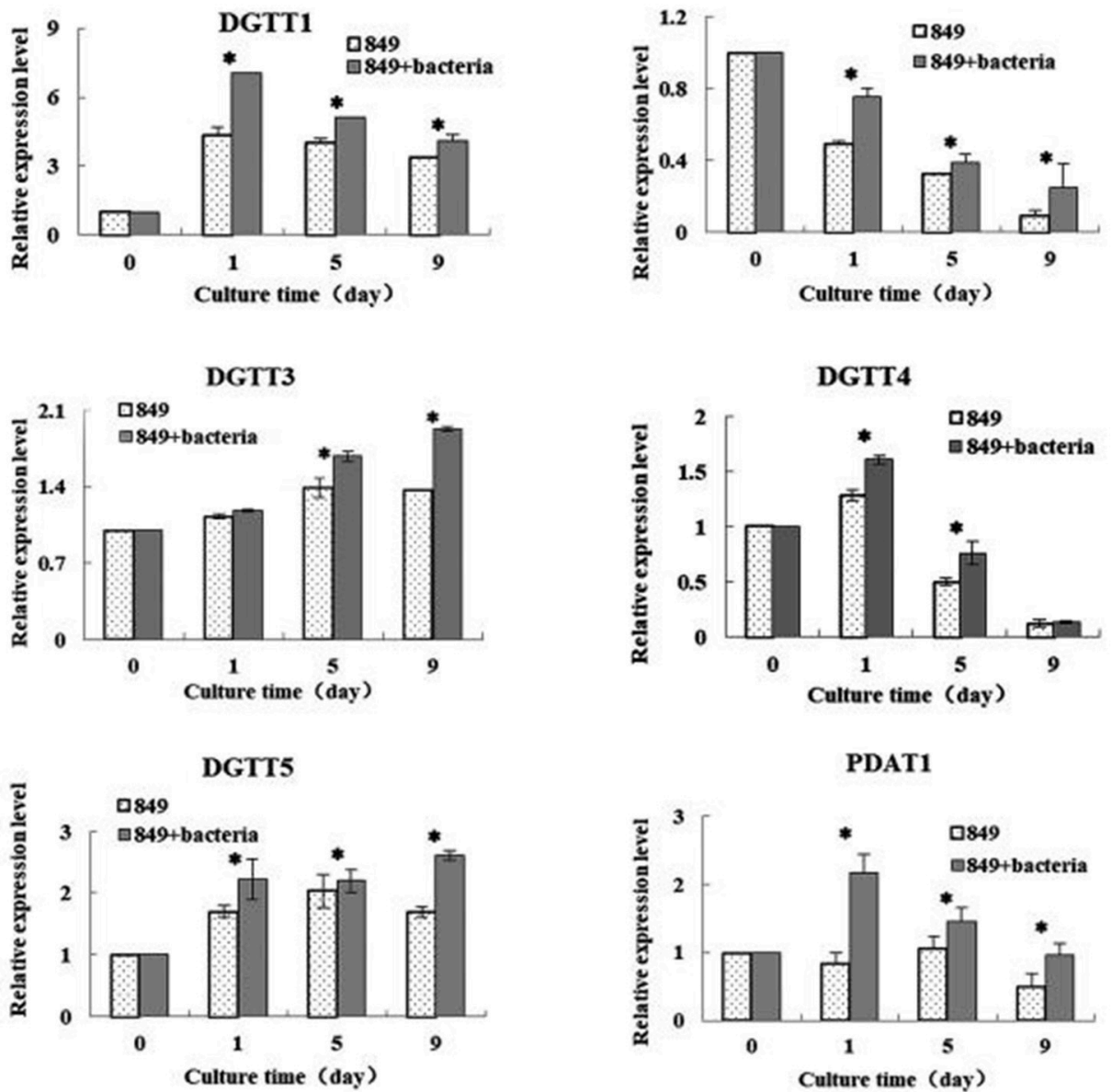

PDAT1
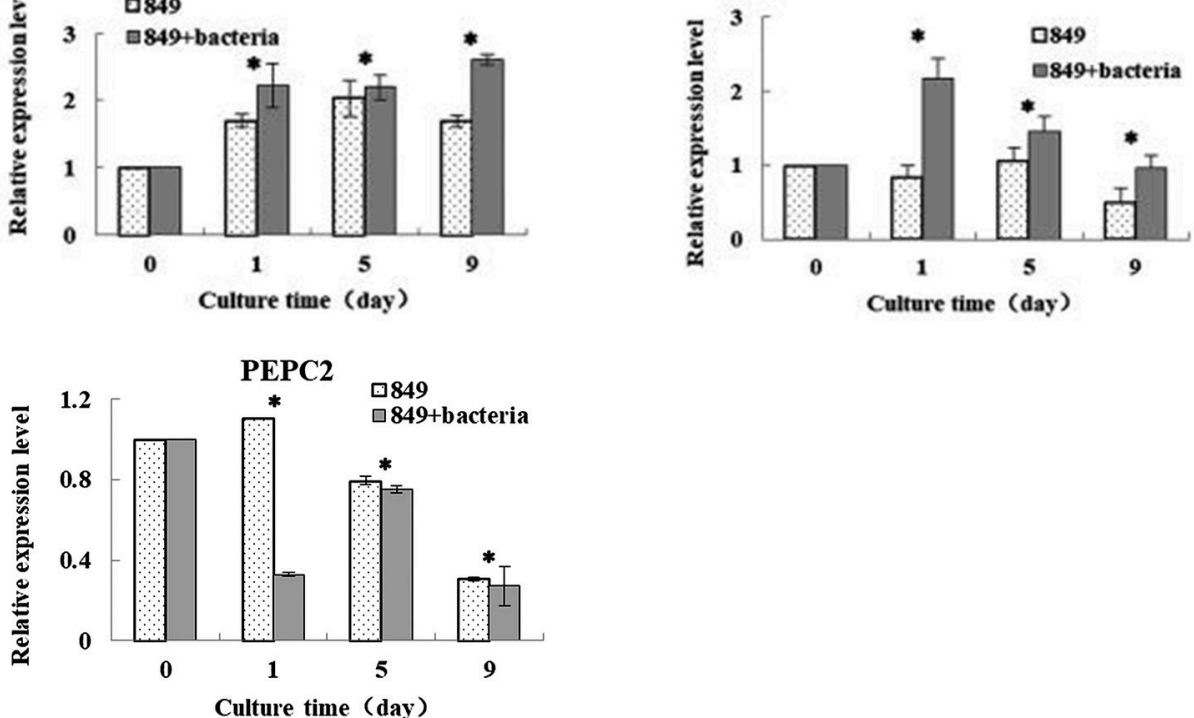

FIGURE 7 | Expression levels of lipid synthesis genes of C. reinhardtii in the co-culture on day 0 (in TAP medium), 1 (the initial stage of lipid production), 5 (logarithmic growth period of lipid production), and 9 (the stable growth period of lipid production) in the TAP-N medium. Examined genes included those encoding diacylglycerol: acetal-CoA carboxylase (ACCase); acyl-CoA aceyltransferases type 1 (DGAT1); and type 2 (DGTT1, DGTT2, DGTT3, and DGTT4); phosphoenolpyruvate carboxylase (PEPC); Phospholipid: diacylglycerol acyitransferase (PDAT). Algae cells were used as controls. The vertical bars indicate standard errors calculated from at least three independent experiments. 
of the DGTT3 gene showed significant difference on days 5 and $9(p<0.05)$; and the levels of expression of the DGTT4 gene showed significant difference on days 1 and $5(p<0.05)$. Miller et al. (2010) investigated the transcriptomic analysis of photoheterotrophic C. reinhardtii under nitrogen-deprived conditions. In their research, DGTT1 showed a significant increase and the expression of other DGAT genes changed little or not at all. In a study by Msanne et al. (Msanne et al., 2012), DGTT1 and DGTT3 displayed a large increase as a response to nitrogen starvation. Unlike in the current work, DGTT4 was also expressed at a high level. Adding A. chroococcum to the algal culture resulted in a large increase in the expression levels of DGAT1, DATT1, DATT2, DATT3, DATT4, and DATT5, which suggests that the increased expression level of DGAT genes may contribute to lipid synthesis of $C$. reinhardtii co-cultured with $A$. chroococcum subjected to nitrogen starvation. This is another important reason for the increased lipid accumulation of $C$. reinhardtii after addition of $A$. chroococcum to the culture.

The enzyme phosphoenolpyruvate carboxylase (PEPC) is involved in the regulation of photosynthesis and photorespiration. It is also involved in the replenishment of amino acid metabolism. It catalyzes the formation of oxaloacetate into pyruvate and then enters the protein metabolism pathway. As shown in the results of PEPC2 gene expression, we also detected gene encoding in $C$. reinhardtii, PEPC2. In our work, the levels of expression of PEPC2 were determined under nutrient-deficient conditions. The results showed that the level of expression of $C$. reinhardtii co-cultured with A. chroococcum and pure algae decreased from day 1 to day 9 under nutrient-deficient conditions. The levels of the genes expression of $C$. reinhardtii co-cultured with $A$. chroococcum declined much faster than those of the pure algae. The levels of expression of the PEPC gene showed significant differences on days 1,5 , and $9(p<0.05)$. This demonstrated that nitrogen depletion leads to the inhibition of the expression of PEPC2. After the addition of A. chroococcum, the expression of PEPC2 was more severely inhibited. In theory, when PEPC expression is inhibited, more pyruvate will become acetyl-CoA through a process catalyzed by pyruvate dehydrogenase, which facilitates lipid synthesis. Nitrogen as a signal molecule can be induced and regulated by the expression of genes. PEPC gene expression, protein content and PEPC gene activity were highly positive (Sugimoto et al., 1989; Chen et al., 1998). Therefore, PEPC plays a negative regulatory role in lipid production. Blocking the PEPC gene can increase lipid accumulation in many species (Sugimoto et al., 1989; Chen et al., 1998). Lipid content increases dramatically with decreased expression of the PEPC2 gene in $C$. reinhardtii under nitrogen-deficient conditions (Deng et al., 2011). This is consistent with our results.

Phospholipid diacylglycerol acyltransferase (PDAT) is an acylCoA independent enzyme that transfers the acyl group from the sn-2 position of a phospholipid to the sn-3 position of a diacylglycerol (Boyle et al., 2012). Boyle et al. (2012) reported lipid accumulation by a $C$. reinhardtii mutant lacking the PDAT1 gene at $25 \%$ of wild algae, indicating that PDAT1 plays an important role in the lipid synthesis of $C$. reinhardtii. In our research, the levels of expression of both $C$. reinhardtii in the co-culture and pure $C$. reinhardtii increased with the increased lipid production. The expression levels of C. reinhardtii in the co-culture were higher than those of the control; i.e., adding $A$. chroococcum to the algal culture led to a significant increase in the expression level of the PDAT1 gene in the depletion of the nitrogen medium. The levels of expression of the PDAT1 gene showed significant differences on days 1, 5 and $9(p<0.05)$. Especially, the lowest level of expression of the PDAT1 gene in C. reinhardtii in the co-culture was 1.5 times the control levels on day 9, which is when the lipid content, lipid production, and lipid productivity were the greatest (Figure 3).

\section{CONCLUSIONS}

In this study, we co-cultured C. reinhardtii with $A$. chroococcum to enhance lipid accumulation of $C$. reinhardtii by increasing the growth and biomass of $C$. reinhardtii under nitrogendeprived conditions. After the addition of A. chroococcum, the growth and biomass of $C$. reinhardtii increased, as well as lipid accumulation, lipid content, and lipid productivity. In summary, A. chroococcum improved the lipid accumulation and the activity of $C$. reinhardtii by enhancing the growth, biomass, and levels of expression of genes that positively regulate lipid metabolism and by decreasing the expression levels of genes that negatively regulate lipid metabolism. This study provides an effective method for increasing the lipid production of $C$. reinhardtii by increasing its biomass and through its ecological relationship with A. chroococcum.

\section{AUTHOR CONTRIBUTIONS}

LX and QW proposed the idea and hypothesis. XC carried out the experiment. LX and XC analyzed data and drafted the manuscript. All authors read and approved the final manuscript for publication.

\section{ACKNOWLEDGMENTS}

This work was supported by the National Natural Science Foundation of China (NSFC No. 31600284) and Shanghai Engineering Research Center of Plant Germplasm Resources (No. 17DZ2252700).

\section{SUPPLEMENTARY MATERIAL}

The Supplementary Material for this article can be found online at: https://www.frontiersin.org/articles/10.3389/fpls.2018. 00741/full\#supplementary-material 


\section{REFERENCES}

Bell, W. H., Lang, J. M., and Mitchell, R.,(1974). Selective stimulation of marine bacteria by algal extracellular products. Linnol. Oceanogr. 19, 833-839. doi: 10.4319/lo.1974.19.5.0833

Bligh, E. G., and Dyer, W. J. (1959). A rapid method of total lipid extraction and purification. Can. J. Biochem. Physiol. 37, 911-917. doi: 10.1139/y59-099

Boyle, N. R., Page, M. D., Liu, B., Blaby, I. K., Casero, D., Kropat, J., et al. (2012). Three acyltransferases and nitrogen-responsive regulator are implicated in nitrogen starvation-induced triacylglycerol accumulation in Chlamydomonas. J. Biol. Chem. 287, 15811-15825. doi: 10.1074/jbc.M111.334052

Chen, J., Lang, C., Hu, Z., Liu, Z., and Huang, R. (1998). Antisense PEP gene regulates to ratio of protein and lipid content in Brassica napus seeds. J. Agric. Biotechnol. 7, 316-320.

Chen, W., Zhang, C., Song, L., Sommerfeld, M., and Hu, Q. (2009). A high throughput Nile red method for quantitative measurement of neutral lipids in microalgae. J. Microbiol. Methods 77, 41-47. doi: 10.1016/j.mimet.2009.01.001

Cronan, J. E., and Waldrop, G. L. (2002). Multi-subunit acetyl-CoA carboxylases. Prog. Lipid Res. 41, 407-435. doi: 10.1016/S0163-7827(02)00007-3

Deng, X., Li, Y., and Fei, X. (2011). The mRNA abundance of pepc2 gene is negatively correlated with oil content in Chlamydomonas reinhardtii. Biomass. Bioenerg. 35, 1811-1817. doi: 10.1016/j.biombioe.2011.01.005

Dubois, M., Gilles, K. A., Hamilton, J. K., Rebers, P. A., and Smith, F. (1956). Colorimetric method for determination of sugars and related substances. Anal. Chem. 28, 350-356. doi: 10.1021/ac60111a017

Fan, J. H., Cui, Y. B., Wan, M. X., Wang, W., and Li, X. G. (2014). Lipid accumulation and biosynthesis genes response of the oleaginous Chlorella pyrenoidosa under three nutrition stressors. Biotechnol. Biofuels 7:17. doi: $10.1186 / 1754-6834-7-17$

Gyurjan, I., Turtoczky, I., Toth, G., Paless, G., and Nghia N. H. (1984). Intercellular symbiosis of nitrogen-fixing bacteria and green alga. Acta. Botanica. Hungarica. $30,249-256$.

Harris, E. H. (2009). The Chlamydomonas Sourcebook: Introduction to Chlamydomonas and Its Laboratory Use. San Diego, CA: Academic Press.

Ho, S. H., Chan, M. C., Liu, C. C., Chen, C. Y., Lee, W. L., Lee, D. J., et al. (2014). Enhancing lutein productivity of an indigenous microalga Scenedesmus obliquus FSP-3 using light-related strategies. Bioresour. Technol. 152, 275-282. doi: 10.1016/j.biortech.2013.11.031

Hsieh, C. H., and Wu, W. T. (2009). Cultivation of microalgae for oil production with a cultivation strategy of urea limitation. Bioresour. Technol. 100, 3921-3926. doi: 10.1016/j.biortech.2009.03.019

Hu, Q., Sommerfeld, M., Jarvis, E.,Ghirardi, M., Posewitz, M., Seibert, M., et al., (2008). Microalgal triacylglycerols as feedstocks for biofuel production: perspectives and advances. Plant J. 54, 621-639. doi: 10.1111/j.1365-313X.2008.03492.x

Hui, W., Zhou, W. J., Chen, W. T., Gao, L. L., and Liu, T. Z. (2016). Strategy study on enhancing lipid productivity of filamentous oleaginous microalgae Tribonema. Bioresour. Technol. 218, 161-166. doi: 10.1016/j.biortech.2016.06.083

Ietswaart, I., Schneider, P. J., and Prinsra, R. A. (1994). Utilization of organic nitrogen sources by two phytoplankton species and a bacterial isolate in pure and mixed cultures. Appl. Environ. Microbiol. 60, 1554-1560.

Krakow, J. S., and Ochoa, S. (1963). Ribonucleic acid ribonucleic acid nucleotidyl transferase of Azotobacter vinelandii. IV. Purification and properties. Biochem. Z. 338, 796-808.

Li, Y., Han, D., Sommerfeld, M., and Hu, Q. (2011). Photosynthetic carbon partitioning and lipid production in the oleaginous microalga Pseudochlorococcum sp. (Chlorophyceae) under nitrogen-limited conditions. Bioresour. Technol. 102, 123-129. doi: 10.1016/j.biortech.2010.06.036

Liu, J., Pei, G., Diao, J., Chen, Z., Liu. L., Chen, L., Zhang, W., (2017). Screening and transcriptomic analysis of Crypthecodinium cohnii mutants with high growth and lipid content using the acetyl-CoA carboxylase inhibitor sethoxydim. Appl. Microbiol. Biotechnol. 101, 6179-6191. doi: 10.1007/s00253-0178397-z

Makarova, V. V., Kosourov, S., Krendeleva, T. E., Semin, B. K., Kukarskikh, G. P., Rubin, A. B., et al. (2007). Photoproduction of hydrogen by sulfur-deprived C. reinhardtii mutants with impaired photosystem II photochemical activity. Photosynth. Res. 94, 79-89. doi: 10.1007/s11120-007-9219-4
Miller, R., Wu, G., Deshpande, R. R., Vieler, A., Gärtner, K., Li, X.,et al. (2010). Changes in transcript abundance in Chlamydomonas reinhardtii following nitrogen deprivation predict diversion of metabolism. Plant Physiol. 154, 1737-1752. doi: 10.1104/pp.110.165159

Msanne, J., Xu, D., Konda, A. R., Casas-Mollano, J. A., Awada, T., Cahoon, E. B., et al. (2012). Metabolic and gene expression changes triggered by nitrogen deprivation in the photoautotrophically grown microalgae Chlamydomonas reinhardtii and Coccomyxa sp. C-169. Phytochemistry 75, 50-59. doi: 10.1016/j.phytochem.2011.12.007

Park, J.-J., Wang, H. X., Gargouri, M., Deshpande, R. R., Skepper, J. N., Holguin, F. O., et al. (2015). The response of Chlamydomonas reinhardtii to nitrogen deprivation: a systems biology analysis. Plant J. 81, 611-624. doi: 10.1111/tpj.12747

Park, W.-K., Yoo, G., Moon, M., Kim, C. W., Choi, Y.-E., and Yang, J.W. (2013). Phytohormone supplementation significantly increases growth of Chlamydomonas reinhardtii cultivated for biodiesel production. Appl. Biochem. Biotechnol. 171, 1128-1142. doi: 10.1007/s12010-013-0386-9

Riquelm, C. E., Fukami, K., and Ishida, Y. (1988). Effects of bacteria on the growth of a marine diatom, Asterionella gracialis. Bull. Jap. Soc. Microb. Ecol. 3, 29-34. doi: 10.1264/microbes1986.3.29

Rodolfi, L., Chini Zittelli, G., Bassi, N., Padovani, G., Biondi, N., Bonini, G., et al. (2009). Microalgae for oil: strain selection, induction of lipid synthesis and outdoor mass cultivation in a low-cost photobioreactor. Biotechnol. Bioeng. 102, 100-112. doi: 10.1002/bit.22033

Rubenchik, L. I. (1963). Azotobacter and its uses in agriculture. Soil Sci. 98, 6-8.

Scott, S. A., Davey, M. P., Dennis, J. S., Horst, I., Howe, C. J., Lea-Smith, D. J., et al. (2010). Biodiesel from algae: challenges and prospects. Curr. Opin. Biotechnol. 21, 277-286. doi: 10.1016/j.copbio.2010.03.005

Siaut, M., Cuiné, S., Cagnon, C., Fessler, B., Nguyen, M., Carrier, P., et al (2011). Oil accumulation in the model green alga Chlamydomonas reinhardtii: characterization, variability between common laboratory strains and relationship with starch reserves. BMC Biotechnol. 11:7. doi: 10.1186/1472-6750-11-7

Sugimoto, T., Tanaka, K., Monma, M., Kawamura, Y., and Saio, K. (1989). Phosphoenolpyruvate carboxylase level in soybean seed highly correlates to its contents of protein and lipid. Agric. Biol. Chem. 53, 885-887. doi: $10.1080 / 00021369.1989 .10869369$

Walker, C. C., and Yater, M. G. (1978). The hydrogen cycle in nitrogen-fixing Azotobacter chroococcum. Biochimie 60, 225-231. doi: 10.1016/S0300-9084(78)80818-9

Wan, C., Bai, F.-W., and Zhao, X.-Q. (2013). Effects of nitrogen concentration and media replacement on cell growth and lipid production of oleaginous marine microalga Nannochloropsis oceanica DUT01. Biochem. Eng. J. 78, 32-38. doi: 10.1016/j.bej.2013.04.014

Wan, M., Liu, P., Xia, J., Rosenberg, J. N., Oyler, G. A., Betenbaugh, M. J., et al. (2011). The effect of mixotrophy on microalgal growth, lipid content, and expression levels of three pathway genes in Chlorella sorokiniana. Appl. Microbiol. Biotechnol. 91 , 835-844. doi: 10.1007/s00253-011-3399-8

Wang, H., Gao, L. L., Chen, L., Guo, F. J., and Liu, T. Z. (2013). Integration process of biodiesel production from filamentous oleaginous microalgae Tribonema minus. Bioresour. Technol.142, 39-44. doi: 10.1016/j.biortech.2013.05.058

Wang, Z. T., Ullrich, N., Joo, S., Waffenschmidt, S., and Goodenough, U. (2009). Algal lipid bodies: stress induction, purification, and biochemical characterization in wildtype and starchless Chlamydomonas reinhardtii. Eukaryot Cell. 8, 1856-1868. doi: 10.1128/EC.00272-09

Winogradski, S. (1935). The method in soil microbiology as illustrated by studies on Azotobacter and the nitrifying organisms. Soil Sci. 40, 59-76. doi: 10.1097/00010694-193507000-00009

Wu, S. X., Li, X. X., Yu, J., and Wang, Q. X. (2012). Increased hydrogen production in co-culture of Chlamydomonas reinhardtii and Bradyrhizobium japonicum. Bioresour. Technol. 123, 184-188. doi: 10.1016/j.biortech.2012.07.055

Wu, S. X., Xu, L. L., Wang, R. R., Liu, X. L., and Wang, Q. X. (2011). A high yield mutant of Chlamydomonas reinhardtii for photoproduction of hydrogen. Int. J. Hydrogen Energy 36, 14134-14140. doi: 10.1016/j.ijhydene.2011.05.001

Xu, L. L., Li, D. Z., Wang, Q. X., and Wu, S. X. (2016). Improved hydrogen production and biomass through the co-cultivation of Chlamydomonas reinhardtii and Bradyrhizobium japonicum. Int. J. Hydrogen. Energ. 41, 9276-9283. doi: 10.1016/j.ijhydene.2016.04.009 
Yeesang, C., and Cheirsilp, B. (2011). Effect of nitrogen, salt, and iron content in the growth medium and light intensity on lipid production by microalgae isolated from freshwater sources in Thailand. Bioresour. Technol. 102, 3034-3040. doi: 10.1016/j.biortech.2010.10.013

Yen, H.-W., Hu, I. C., Chen, C.-Y., Ho, S.-H., Lee, D.-J., and Chang, J.-S. (2013). Microalgae-based Biorefinery-from biofuels to natural products. Bioresour. Technol. 135, 166-174. doi: 10.1016/j.biortech.2012.10.099

Zheng, T. L., Xu, M. Z., Yu, Z. M., and Song, X. X. (2002). The variation of bacterial extracellular enzymatic activity under the interaction between bacteria and algae. Mari Sci. $26,41-44$.
Conflict of Interest Statement: The authors declare that the research was conducted in the absence of any commercial or financial relationships that could be construed as a potential conflict of interest.

Copyright (c) $2018 \mathrm{Xu}$, Cheng and Wang. This is an open-access article distributed under the terms of the Creative Commons Attribution License (CC BY). The use, distribution or reproduction in other forums is permitted, provided the original author(s) and the copyright owner are credited and that the original publication in this journal is cited, in accordance with accepted academic practice. No use, distribution or reproduction is permitted which does not comply with these terms. 